International Journal of Environment, Agriculture and Biotechnology
Vol-6, Issue-4; Jul-Aug, 2021
JUAB
$\begin{gathered}\text { Journal Home Page Available: } \text { https://ijeab.com/ } \\ \text { Journal DOI: } 10.22161 / \text { ijeab }\end{gathered}$

Article

Peer-Reviewed Journal

\title{
Effect of Vermicompost and Terrestrial Isopod (Porcellio laevis) Fertilizers on The Yield and Quality of Lettuce (Lactuca sativa var. capitata cv. Wismar)
}

\author{
Levent Arın ${ }^{1 *}$, Hilal Dinçsoy ${ }^{1}$, Sırrı Kar ${ }^{2}$
}

\author{
${ }^{1}$ Department of Horticulture, Tekirdağ Namık Kemal University, Turkey \\ ${ }^{2}$ Department of Biology, Tekirdağ Namık Kemal University, Turkey \\ *Corresponding Author
}

Received: 01 Jul 2021; Received in revised form: 14 Jul 2021; Accepted: 22 Jul 2021; Available online: 03 Aug 2021 (C)2021 The Author(s). Published by Infogain Publication. This is an open access article under the CC BY license (https://creativecommons.org/licenses/by/4.0/).

\begin{abstract}
Terrestrial isopods (woodlice) (Isopoda.: Oniscidea) are important members of soil macrofauna in many habitats. Although the role of woodlice in decomposing organic matter and recycling nutrients is well known, there is no available data on the utilization of fertilizer obtained using terrestrial isopods in agricultural production. To evaluate the effects of the addition of vermicompost and the fertilizer obtained using terrestrial isopod species Porcellio laevis Latreille, 1804 in different ratios to plant growing media on nutrient content and yield of lettuce, nine different mixtures containing $1,5,10$, and $20 \%$ of each fertilizer [v/ $\mathrm{v}$, including agricultural soil (control)] were used. As result, while the total and head weight of the control plant was $69.66 \mathrm{~g}$ and $59.53 \mathrm{~g}$ respectively, the highest values were obtained from the mixtures containing 20\% vermicompost with $154.33 \mathrm{~g}$ and $150.66 \mathrm{~g}$, and this followed by isopod fertilizer (20\%). The vitamin C and chlorophyll (SPAD) content of plants grown in all mixtures were higher than control and there were no significant differences in respect to phenolic matter and nitrate. The fertilizer produced by using P. laevis, which can evaluate many kinds of agricultural and household organic wastes can be confidently used or added to media.
\end{abstract}

Keywords - Lettuce, Porcellio laevis, quality, Terrestrial isopod, vermicompost.

\section{INTRODUCTION}

Lettuce, a cool-season crop rich in Vit C, A, and minerals, is the major salad vegetable in many countries of the world also in Turkey (Yamaguchi 1983; Liebster 1990; Krug 1991). It has nutritious properties and important for a balanced diet. Existing (conventional) agricultural production systems are threatening living and environmental health. For instance, the excessive use of nitrogen for high yield is a widespread practice, especially in leafy vegetables like lettuce. This situation not only the soil's ability to produce healthy plants affect, but also causes salinization and pollution in soil and groundwater. Therefore, there is a demand for naturally derived plant nutrient elements and soil conditioners for the sustainability of agriculture and healthy vegetable products. In this context, it is increasing the interest in the use of materials such as vermicompost, especially for the utilization of agricultural wastes and environmentally friendly sustainable production. Vermicompost, processed organic material by earthworm, which is increasingly used in agricultural practices, has high porosity, drainage, water-holding capacity, and microbial activity. It improves absorbability and retention of nutrient due to having a large surface area, and thus contain nutrients in forms that are readily taken up by the plants. There are a number of researches in the literature dealing with the positive influence of vermicompost on growth, productivity and quality of vegetables (Edwards and Burrows 1988; Orozco et al. 1996; Atiyeh et al. 1999; Sharma and Banik 2014).

Terrestrial isopods (Isopoda: Oniscidea), a member of soil macrofauna, are invertebrate species that playing an important role in the decomposition of agriculture and 
livestock waste material (Drobne 1997; Odendaal and Reinecke 1999; Hussein et al. 2006; Loureiro et al. 2006). They are identified as an integral part of the decomposition process, which recycles essential nutrients of the soil and maintains its fertility by the fragmentation of organic matter and stimulating and/or ingesting fungi and bacteria. Due to their high physiological adaptation capacity and exhibiting a broad distribution, they have become an important model organism for the monitoring of pollution and to test the hypotheses in global change biology (Kammenga et al. 2000; Zimmer 2002). Porcellio laevis is one of the most widely and intensively used woodlice species for this purpose, as it is cosmopolitan and shows plasticity in physiological and life-history traits in response to different geographical climatic condition (Powers and Bliss 1983; Castañeda et al. 2004; Bacigalupe et al. 2007; Lardies and Bozinovic 2008; Folguera et al. 2009; Da Silva Junior et al. 2014).

Nowadays, many ingredients such as vermicompost, perlite, coir, and peat are used to improve the qualifications of growing media in growing seedling and horticultural crops (Tuzel et al. 2020). Furthermore, interest in different resources to be used for this purpose in the production of horticultural crops is increasing due to reasons such as increased environmental awareness, high input cost, and increasing demand for waste recycling. Although many studies have reported the positive impacts of vermicompost on the growth and yield of vegetable crops, to our knowledge, no information is available on the role of woodlice-mediated fertilizer in crop production. The main objective of this study was to evaluate the usability of terrestrial isopod (Porcellio laevis) fertilizer added to growing media at different proportions for lettuce production and to compare it with vermicompost.

\section{MATERIALS AND METHODS}

\subsection{Isopod fertilizer and preparing}

In this study, agricultural soil, vermicompost, and isopod fertilizer were used as the main media to show the usability potential of woodlice-mediated fertilizer in horticulture through comparative data. The agricultural soil was taken from the vegetable research field of the department of horticulture to prepare growing media had the clay loam texture $(35.13 \%$ clay, $24.40 \%$ silt, $40.47 \%$ sand). Cow manure vermicompost, processed by red earthworm (Eisenia foetida L.), suitable for vegetable production was provided by a commercial firm. To prepare isopod fertilizer, the plastic pot having dimensions 40x50x40 cm was used. Firstly, three-liter agricultural soil was put into the pot, laid to cover the bottom, soaked with tap water, and compressed to a depth of about 1-2 cm.
Then, two kg dry cow manure (old cow dung), lettuce and carrot waste, wheat straw (each one $0.5 \mathrm{~kg}$ ) were added. The mixture was stirred thoroughly and again was moistened. Three hundred adult $P$. laevis longer than 8 $\mathrm{mm}$ were collected from the field, identified morphologically according to the species-specific keys (Hale, 1927-1929), released into the pot, and the container was covered with fine mesh and left at room temperature for three months (Fig. 1a). During this composting period, the studied settlement was regularly checked at intervals of no more than one week. The contents were moistened and mixed gently to allow the isopods to access the different parts of foods, and new food materials were provided when it is necessary. At this point, in order to prevent the excessed food supply from spontaneously decomposing into the fertilizer independently of the isopod effect, food particles that were covered with mold were removed. In all the rearing processes of the isopods, the known data about their environment preferences, moisture requirements, food preferences, daily feed consumption amounts, and other requirements were considered (Warburg 1993; Zimmer 2002; Lardies et al. 2004; Catalán et al. 2008). At the end of the three-month composting period, all the contents were gently sieved (pore size, $c a .3 \times 3 \mathrm{~mm}$ ) to eliminate insufficiently decomposed food pieces and the isopods. Some chemical properties of the agricultural soil, isopod fertilizer) and vermicompost used in the experiments were determined using (Table 1).

By taking into consideration the previous studies (Edwards and Burrows 1988; Ali et al. 2007; Kiran 2019) concerning vermicompost, the following growing media were tested in the experiments:

(1) Agricultural soil (collected from the top $30 \mathrm{~cm}$ depth)

(2) Agricultural soil mixed with $1 \%$ vermicompost (v/v)

(3) Agricultural soil mixed with 5\% vermicompost (v/v)

(4) Agricultural soil mixed with $10 \%$ vermicompost (v/v)

(5) Agricultural soil mixed with $20 \%$ vermicompost (v/v)

(6) Agricultural soil mixed with $1 \%$ isopod fertilizer (v/v)

(7) Agricultural soil mixed with 5\% isopod fertilizer (v/v)

(8) Agricultural soil mixed with $10 \%$ isopod fertilizer (v/v)

(9) Agricultural soil mixed with $20 \%$ isopod fertilizer (v/v)

\subsection{Experiment site, plant materials, and growth conditions}

The experiments on the lettuce cultivation were carried out at the unheated greenhouse of the experimental field of the Department of Horticulture, Faculty of Agriculture,

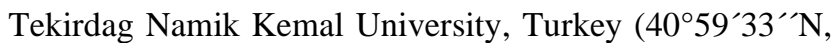
$27^{\circ} 34^{\prime} 43^{\prime \prime} \mathrm{E}$, altitude $18 \mathrm{~m}$ ). Seedlings of commercial lettuce (Lactuca sativa L.), iceberg type, 'Wismar' (Vilmorin-Anadolu Vegetable Seeds, Istanbul, Turkey) 
were planted into bags (dimension in $22 \times 40 \mathrm{~cm}$ ) containing soil and vermicompost or isopod fertilizer at different ratios. Bags were put on benches inside the greenhouse. In order to clearly see the effect of different growing media, no additional fertilization was made during the growing period. Regular watering by hand to keep the soil with adequate water supply was made. Towards the end of the experiment, low tunnels were set up over the plants and covered with shade cloth to protect the plants from high temperatures. (Fig. 1b). Maximum and minimum temperatures and relative humidity were recorded daily during the experiment period (Fig. 2).

Table 1. The basic chemical properties of the agricultural soil, isopod fertilizer (If) and vermicompost (Vc) used in the experiments.

\begin{tabular}{|c|c|c|c|c|c|c|c|c|c|c|c|c|c|}
\hline & & & & Organi & & & & & & & & & \\
\hline & $\mathrm{pH}$ & $\begin{array}{l}\text { Salt } \\
(\%)\end{array}$ & $\begin{array}{l}\text { Lime } \\
(\%)\end{array}$ & $\begin{array}{l}\mathrm{c} \\
\text { matter } \\
(\%)\end{array}$ & $\begin{array}{c}\mathrm{N} \\
(\%)\end{array}$ & $\begin{array}{c}\mathrm{P} \\
(\mathrm{ppm})\end{array}$ & $\begin{array}{c}\mathrm{K} \\
(\mathrm{ppm})\end{array}$ & $\begin{array}{c}\mathrm{Ca} \\
(\mathrm{ppm})\end{array}$ & $\begin{array}{c}\mathrm{Mg} \\
(\mathrm{ppm})\end{array}$ & $\begin{array}{c}\mathrm{Fe} \\
(\mathrm{ppm})\end{array}$ & $\begin{array}{c}\mathrm{Cu} \\
(\mathrm{ppm})\end{array}$ & $\begin{array}{c}\mathrm{Zn} \\
(\mathrm{ppm})\end{array}$ & $\begin{array}{c}\mathrm{Mn} \\
(\mathrm{ppm})\end{array}$ \\
\hline Soil & 7.74 & 0.13 & 4.72 & 1.73 & 0.025 & 32.31 & 95.37 & 531.41 & 56.20 & 0.43 & 1.37 & 0.71 & 16.07 \\
\hline If & 7.02 & 0.74 & 1.71 & 6.52 & 0.33 & 480.61 & 9591.45 & 7763.27 & 2528.88 & 6.89 & 3.18 & 42.43 & 21.59 \\
\hline $\mathrm{Vc}$ & 6.08 & 0.22 & - & 42.80 & 1.40 & 2619.71 & 2945.74 & 4455.50 & - & - & - & - & - \\
\hline
\end{tabular}
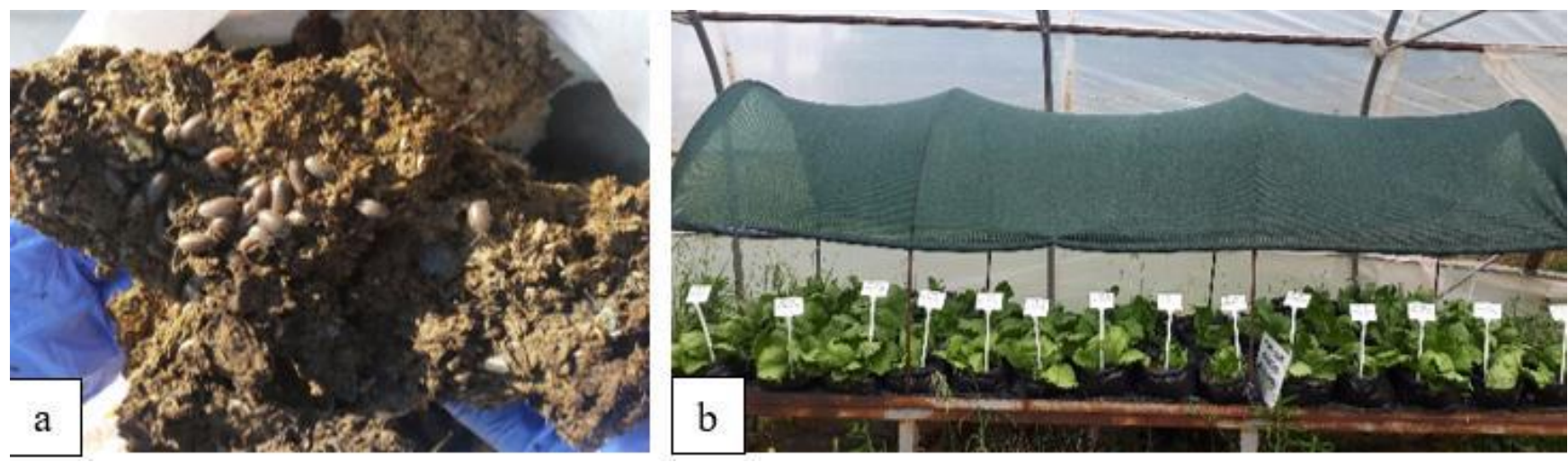

Fig.1. Isopods (Porcellio laevis) (a) and a view of plants grown in a greenhouse (b).

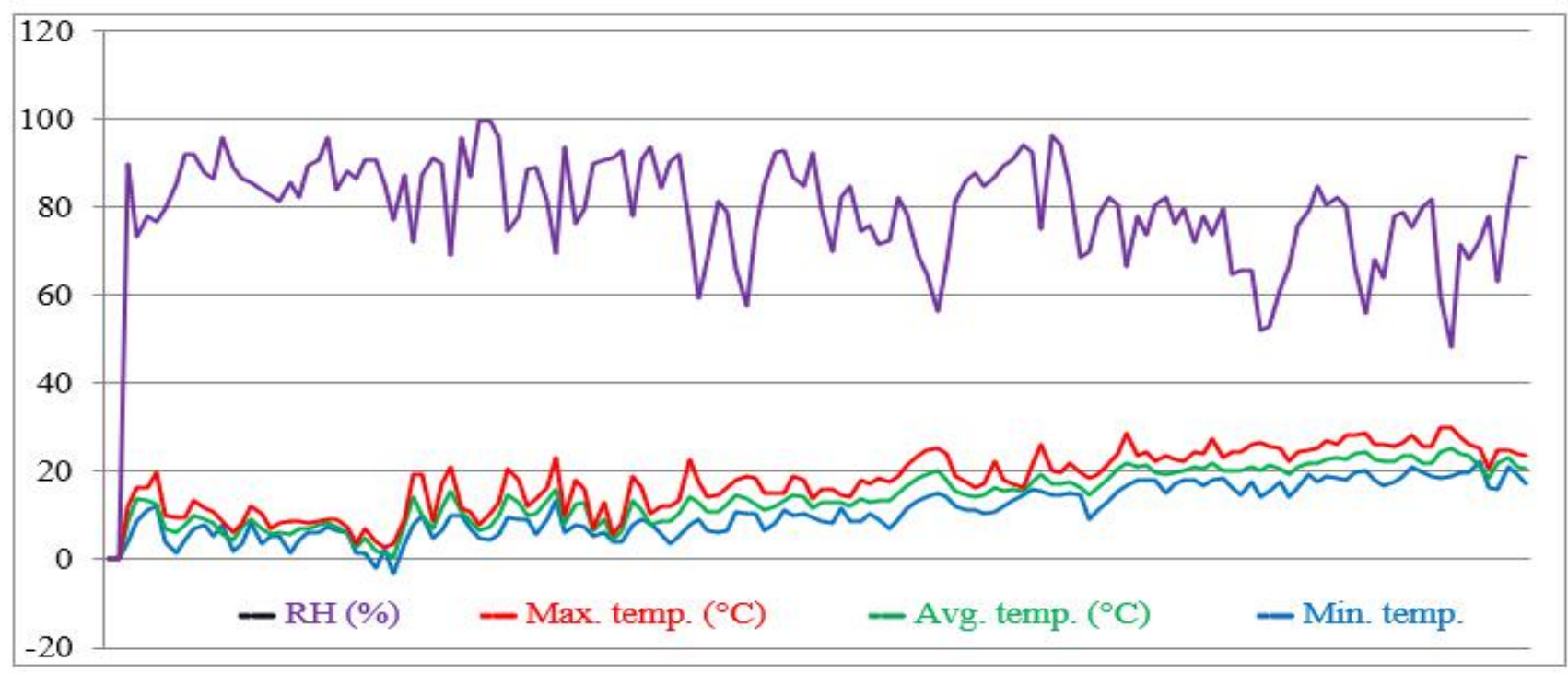

Fig.2: Daily relative humidity $(\mathrm{RH}, \%)$, minimum, maximum and average temperatures $\left({ }^{\circ} \mathrm{C}\right)$ during the growing period.

2.3 Measurement and analysis of plant

ISSN: $2456-1878$

https://dx.doi.org/10.22161/ijeab.64.8
After 60 days from transplanting all plants were harvested by cutting above soil surface using a steel knife, and plant 
weight (without roots), head weight, and head circumference were weighed or measured in the samples randomly selected from each plot and application. Vitamin $\mathrm{C}$ was determined by using the 2,6, dichlorophenolindophenol dye titration according to Pearson (1970) and presented as $\mathrm{mg} / 100 \mathrm{~g}$ fresh weight. Chlorophyll content of leaves was measured nondestructively by Minolta Chlorophyll Meter-SPAD 501 (Ghoname et al. 2017). The content of the total phenolic compounds was determined by Folin-Ciocalteu assay and was expressed as $\mathrm{mg}$ gallic acid equivalent/100 $\mathrm{g}$ of sample (Leamsomrong et al. 2009). The nitrate content of leaves was determined by salicylic acid method and expressed as ppm (Cataldo et al. 1975). Nitrogen was quantified by micro-Kjeldahl method in dried and ground leaf samples, the determination of mineral content of leaf was used atomic absorption spectrophotometer (Hernandez et al. 2010).

\subsection{Statistical analyzes}

The experiment design was a randomized complete block with three replications, each including nine different growing media. Data were subjected to analysis of variance (ANOVA), followed by the LSD test at $p<0.05$ (Montgomery 1991).

\section{RESULTS AND DISCUSSION}

\subsection{Head properties}

The addition of vermicompost ( $\mathrm{Vc}$ ) or isopod fertilizer (If) to the growing medium led to an increase in plant and head weight, and this increase showed a linear relationship with the amount of them (Table 2). The highest plant and head weights were obtained from $20 \% \mathrm{Vc}$ with $154.33 \mathrm{~g}$. and $150.66 \mathrm{~g}$. respectively, this was followed by media containing the same proportion of If with $137.77 \mathrm{~g}$. and $135.00 \mathrm{~g}$. The same situation was also seen in the head circumference and plants growing in medium containing $\mathrm{Vc}$ and If had larger heads than the soil (control). The addition of $\mathrm{Vc}$ or If to the growing medium may have brought the soil $\mathrm{pH}$ closer to neutral. Likewise, the fact that they contain a higher rate of nutrients than the soil may have led to this result. Similar to the results obtained from this experiment, as reported by many authors (e.g., Hernandez et al. 2010; Singh et al. 2010; Sharma and Banik 2014), the addition of vermicompost to the medium increases plant growth. Nagavallemma et al. (2006) stated that the application of vermicompost can directly modify the physicochemical properties of agricultural soil in a way that promotes plant growth. In our previous study that the vermicompost and isopod fertilizers at the same ratio were added to the lettuce seedling growing medium, there was no difference among applications in terms of seedling emergence and seedling characteristics, probably due to the short seedling growing time. However, fresh and dry weights of seedlings in If and Vc media were higher than those grown in soil (Arın and Dinçsoy 2020).

\subsection{Nutrient composition and mineral content}

The vitamin $\mathrm{C}$ and chlorophyll contents of plants grown in media containing vermicompost and isopod fertilizers were higher than the soil (control), and this increase was parallel to the amount of them at media (Table 2). Besides all applications have a higher value than control, the highest SPAD value was recorded at $20 \%$ vermicompost with 38.56 (a), followed by $20 \%$ isopod fertilizer with $35.91(\mathrm{ab})$. A similar case existed in the results regarding the vitamin $\mathrm{C}$ content of the leaves. The likely reason for the increase in vitamin $\mathrm{C}$, chlorophyll, with the addition of these to the growing medium, could be that these materials contain higher organic matter and plant nutrient elements compared to the soil (Table 1). Other hand, Kiran (2019) stated that vermicompost increases water uptake of roots due to its capacity of holding water and the microorganisms including mycorrhizal fungi. Ayyobi et al. (2014) reported that the increase in chlorophyll content with organic matter applications such as vermicompost or municipal solid waste compost can be attributed to an increase in photosynthesis and $\mathrm{CO}$ assimilation which improve mineral uptake by the plant.

There were no significant differences among the content of phenolic matters of plants grown in different media but, the lowest value with $175.33 \mathrm{mg} / 100 \mathrm{~g}$ was determined in control (soil). Also, in terms of nitrate, the differences of growing media were not statistically important (Table 2). It is known that excess nitrate is harmful to human health. During various processes in the human body, nitrates are converted into nitrites, which causes various diseases, such as blue baby syndrome (methemoglobinemia) and cancer. Leafy vegetables, including lettuce, are plants that accumulate high amounts of nitrate (Mensinga et al. 2003; Colla et al. 2018; Bian et al. 2020; Salehzahed et al. 2020). Gorenjak and Cencic (2013) reported that lettuce takes place in the remarkably high group in the classification made according to the nitrate content of vegetables, Krug (1991) that the nitrate content of lettuce varies $380-3520 \mathrm{mg} / \mathrm{kg} \mathrm{FW}$ as depending on many factors such as the variety, growing season and fertilization. According to EU Commission regulation (No 1258/2011), concerning with maximum nitrate content for the commercialization of fresh vegetable, the nitrate threshold established for lettuce is $3000-5000 \mathrm{mg} / \mathrm{kg} \mathrm{FW}$, and the highest daily nitrate intake $222 \mathrm{mg}$ for a $60 \mathrm{~kg}$ individual (Colla et al. 2018). In this study, besides the nitrate content of lettuce leaves was not significantly affected by the addition of vermicompost or isopod fertilizers to growing media, the nitrate levels of the plants 
were within the aforementioned values or did not exceed

the recommended maximum nitrate intake value per day.

Table 2. The effect of different growing media on the plant weight $(\mathrm{g})$, head weight $(\mathrm{g})$, head circumference (cm), vitamin $C$ (mg/lo0g), chlorophyll (SPAD), total phenol (mg/lo0g), nitrate content of lettuce (ppm).

\begin{tabular}{|c|c|c|c|c|c|c|c|}
\hline & $\begin{array}{c}\text { Plant } \\
\text { weight (g) }\end{array}$ & $\begin{array}{c}\text { Head } \\
\text { weight (g) }\end{array}$ & $\begin{array}{l}\text { Head } \\
\text { circum. } \\
(\mathrm{cm})\end{array}$ & $\begin{array}{l}\text { Vitamin C } \\
(\mathrm{mg} / 100 \mathrm{~g})\end{array}$ & $\begin{array}{c}\text { Chlorophyll } \\
\text { (SPAD) }\end{array}$ & $\begin{array}{c}\text { Total phenol } \\
(\mathrm{mg} / 100 \mathrm{~g})\end{array}$ & $\begin{array}{r}\text { Nitrate } \\
(\mathrm{ppm})\end{array}$ \\
\hline Soil & $69.66 \mathrm{~d}$ & $59.53 \mathrm{~d}$ & $28.7 \mathrm{~b}$ & $9.47 \mathrm{f}$ & $24.37 \mathrm{c}$ & 175.3 & 1064.0 \\
\hline $1 \% \mathrm{Vc}^{*}$ & $99.67 \mathrm{bcd}$ & $96.33 \mathrm{bcd}$ & $37.0 \mathrm{ab}$ & $11.90 \mathrm{de}$ & $28.35 \mathrm{bc}$ & 195.6 & 1230.5 \\
\hline $5 \% \mathrm{Vc}$ & $112.00 \mathrm{abc}$ & $108.66 \mathrm{abc}$ & $41.3 \mathrm{a}$ & $13.97 \mathrm{~cd}$ & $30.95 \mathrm{abc}$ & 248.0 & 1256.0 \\
\hline $10 \% \mathrm{Vc}$ & $128.00 \mathrm{ab}$ & $125.33 \mathrm{ab}$ & $41.0 \mathrm{a}$ & $16.43 \mathrm{ab}$ & $31.49 \mathrm{abc}$ & 184.6 & 1070.0 \\
\hline $20 \% \mathrm{Vc}$ & $154.33 \mathrm{a}$ & $150.66 \mathrm{a}$ & $42.0 \mathrm{a}$ & $18.68 \mathrm{a}$ & $38.56 \mathrm{a}$ & 218.7 & 1433.5 \\
\hline $1 \%$ If** & $79.00 \mathrm{~cd}$ & $76.33 \mathrm{~cd}$ & $35.0 \mathrm{ab}$ & $11.62 \mathrm{ef}$ & $28.99 \mathrm{bc}$ & 179.3 & 2164.5 \\
\hline $5 \%$ If & $93.20 \mathrm{bcd}$ & $90.33 \mathrm{bcd}$ & $34.0 \mathrm{ab}$ & $12.16 \mathrm{de}$ & $29.12 b c$ & 230.7 & 1189.5 \\
\hline $10 \%$ If & $120.33 \mathrm{abc}$ & $116.66 \mathrm{abc}$ & $33.6 \mathrm{ab}$ & $15.46 \mathrm{bc}$ & $31.29 \mathrm{abc}$ & 254.6 & 1972.5 \\
\hline $20 \%$ If & $137.77 \mathrm{ab}$ & $135.00 \mathrm{ab}$ & $39.4 \mathrm{a}$ & $16.83 \mathrm{ab}$ & $35.91 \mathrm{ab}$ & 192.0 & 1745.5 \\
\hline
\end{tabular}

Within columns, values followed by different letters are significantly different $(P<0.05)$

*Vc: Vermicompost, **If: Isopod fertilizer

The differences in the mineral content of the leaves among growing media were not significant except for zinc. With the increase of isopod fertilizer in the mixture, the zinc content of the leave increased regularly and the highest zinc content with $11.58 \mathrm{ppm}$ was determined at $20 \%$ If (Table 3). As known well, Zinc has a particularly important role in protein synthesis, membrane stability, and enzyme activation in plants, and it supports and activates the plant immune and resistance system, especially in stressful conditions (Cakmak 2008; Rehman et al. 2019; Farooq et al. 2021).

Table 3. The effect of different growing media on the mineral content of lettuce leaves.

\begin{tabular}{|c|c|c|c|c|c|c|c|c|c|c|c|}
\hline & $\begin{array}{c}\mathrm{N} \\
(\%)\end{array}$ & $\begin{array}{c}\mathrm{P} \\
(\mathrm{ppm})\end{array}$ & $\begin{array}{c}\mathrm{K} \\
(\mathrm{ppm})\end{array}$ & $\begin{array}{c}\mathrm{Ca} \\
(\mathrm{ppm}\end{array}$ & $\begin{array}{c}\mathrm{Mg} \\
(\mathrm{ppm})\end{array}$ & $\begin{array}{c}\mathrm{Na} \\
(\mathrm{ppm})\end{array}$ & $\begin{array}{c}\mathrm{Mn} \\
(\mathrm{ppm})\end{array}$ & $\begin{array}{c}\mathrm{Zn} \\
(\mathrm{ppm})\end{array}$ & $\begin{array}{c}\mathrm{Cu} \\
(\mathrm{ppm})\end{array}$ & $\begin{array}{c}\text { B } \\
\text { (ppm) }\end{array}$ & $\begin{array}{c}\mathrm{Fe} \\
(\mathrm{ppm})\end{array}$ \\
\hline Soil & 0.93 & 7187.3 & 8762.6 & 11105.9 & 1717.5 & 1511.5 & 41.20 & $8.53 \mathrm{bc}$ & 1.33 & 12.70 & 650.8 \\
\hline $1 \% \mathrm{Vc} *$ & 0.97 & 5601.2 & 8213.4 & 10581.4 & 1641.5 & 1524.8 & 43.26 & $7.46 \mathrm{bcd}$ & 1.32 & 12.42 & 872.7 \\
\hline $5 \% \mathrm{Vc}$ & 1.10 & 7329.2 & 15254.8 & 10347.7 & 1441.6 & 1422.1 & 39.58 & $7.03 \mathrm{bcd}$ & 1.15 & 9.63 & 445.0 \\
\hline $10 \% \mathrm{Vc}$ & 1.08 & 5741.8 & 6467.4 & 9295.6 & 1502.3 & 1375.1 & 34.70 & $6.08 \mathrm{~d}$ & 1.10 & 6.53 & 481.8 \\
\hline $20 \% \mathrm{Vc}$ & 1.05 & 6348.9 & 11987.3 & 9554.7 & 1310.6 & 1270.1 & 33.68 & $6.60 \mathrm{~cd}$ & 1.23 & 9.20 & 597.7 \\
\hline $1 \%$ If** & 0.87 & 6735.5 & 13471.2 & 10566.8 & 1581.1 & 1533.2 & 37.05 & $8.16 \mathrm{bcd}$ & 1.15 & 7.30 & 448.7 \\
\hline $5 \%$ If & 0.88 & 6649.0 & 5056.8 & 10128.8 & 1609.0 & 1425.5 & 40.56 & $8.63 \mathrm{bc}$ & 1.27 & 13.57 & 794.3 \\
\hline $10 \%$ If & 0.76 & 8053.7 & 10908.5 & 11017.2 & 1848.8 & 1574.3 & 35.75 & $9.00 \mathrm{~b}$ & 0.98 & 11.05 & 561.0 \\
\hline $20 \%$ If & 1.14 & 8046.0 & 6311.0 & 10222.4 & 1677.0 & 1553.3 & 39.33 & $11.58 \mathrm{a}$ & 1.38 & 9.80 & 608.3 \\
\hline
\end{tabular}

Within columns, values followed by different letters are significantly different $(P<0.05)$

*Vc: Vermicompost, **If: Isopod fertilizer 


\subsection{Evaluation of results as deals with health, environment, and agriculture}

The use of sustainable organic materials can increase fertility without negative effects on human health and the environment. They maintain quantity and quality of yield and can be less costly than synthetic fertilizers. Vermicompost is widely one of the most used materials for this purpose. However, it should be kept in mind that the content and characteristics of vermicompost vary depending on the raw material, the type of earthworm, the methods of processing, etc. and it has a high cost and can cause salinity when used continuously or at high rates (Atiyeh et al. 2002; Ayyobi et al. 2014; Guiterrez-Miceli et al. 2007). Today is being emphasized the importance of sustainability to protect human life, animals, and plants by cutting pollution. Therefore, within the scope of zero waste, studies are being carried out and the decisions and measures are taking to reach this goal (Marshall and Farahbakhsh 2013; Lim et al. 2015). The European Union, which has focused on environmental and social sustainability issues such as combating climate change, reducing greenhouse gas emissions, and using renewable energy published a new environmental plan called The European Green Deal in November 2019 (EU Commission 2020). All the relevant data indicate that the interest in materials that can be used as plant nutrients and as soil conditioners from waste with natural processes will continue to increase.

This study suggested that woodlice can be a promising alternative that may be utilized in the eco - friendly agricultural practices. Furthermore, our results and observations, and some well-known features of $P$. laevis as follows indicate that this species is a good candidate in this context: i) it can effectively feed on a great variety of fresh or dead plant materials (Warburg 1993) and dry cattle feces, ii) it is able to avoid the foods contaminated with some heavy metal (Odendaal and Reinecke 1999), iii) it ingests more food than some other woodlice species (Dallinger and Wieser 1977; Warburg 1993), iv) the retention time of food in the digestive tract is mostly less than $24 \mathrm{~h}$, depending on some factors such as food quality (Zimmer 2002), v) it is bigger than many other species, and the adults can reach a length of about $13 \mathrm{~mm}$ (Amari et al. 2019), vi) during the life span that can be as long as two years (Nair et al. 1976; Amari et al. 2019), each female can breed repeatedly (interoparous), the number of broods per year is usually two under field condition (Warburg 1993), this number is most probably higher under constant proper circumstances, and the number of eggs per female in each brood can exceed 100, depending on the size of individual, food quality, and some other environmental conditions (Amari et al. 2019), vii) it has cosmopolitan distribution over the world and synanthropic feature, is commonly associated with stables, cattle yards, and dung heaps, and can effectively inhabit such indoors (Pierce 1907; Harding 2016), viii) it is predominantly active during the night (nocturnal) or at the shady shelters (Warburg 1993), therefore it does not need direct sunlight, ix) it has obviously higher interest in elevated humidity and lower desiccation resistance compared to most other terrestrial isopods (Warburg 1993; Ghemari et al. 2016), taking advantage of that it is fast (Pierce 1907) and timid species, it is easy to get them to gather at a humidified focus in the rearing container, and $\mathrm{x}$ ) its integument characteristics are different from most of the other woodlice species (Warburg 1993), in shiny and fine appearance, and possibly the content of the chitin is less than some other species such as Armadillo officinalis and Porcellio dilatatus. Furthermore, we are also of the opinion that most of these characteristics indicate that $P$. laevis reared for fertilizer production has the potential to be used as animal feed additive.

\section{CONCLUSION}

Results show that the tested vermicompost and terrestrial isopod fertilizer in the present study can improve the yield and quality of lettuce, and the isopod fertilizer was as effective as the vermicompost. Considering that vermicompost production is a high cost and technical method, and knowledge for producing are required, isopod fertilizer may be preferred due to it is a cheap, simple, eco - friendly method that does not require highly equipped facility. Moreover, by this way, agricultural and household organic wastes will be evaluated, and useful recycling will be provided through isopod fertilizer production.

\section{DECLARATION OF INTEREST}

The authors declare that they have no competing interests.

\section{REFERENCES}

[1] Ali M, Griffiths AJ, Williams KP, Jones DL. 2007. Evaluating the growth characteristics of lettuce in vermicompost and green waste compost. Eur J Soil Biol. 43:5316-5319.

[2] Amari T, Zaabar W, Semmar N, Souty-Grosset C, Achouri MS. 2019. Porcellio laevis (Crustacea, Isopoda) from soil detritivore to vegetable crop pest: case study of the melon (Cucumis melo L., Cucurbitaceae). Vie et milieu - Life and environment. 69:123-135.

[3] Arın L, Dinçsoy H. 2020. Effect of vermicompost and isopod (Porcellio laevis) fertilizers on the emergence and 
seedling quality of lettuce (Lactuca sativa var. capitata cv. Wismar). Int J Agric Environ Food Sci. 4:501-506.

[4] Atiyeh RM, Subler S, Edwards CA, Metzger J. 1999. Growth of tomato plants in horticultural potting media amended with vermicompost. Pedobiologia. 43:724-729.

[5] Atiyeh RM, Arancon NQ, Edwards CA, Metzger JD. 2002. The influence of earthworm-processed pig manure on the growth and productivity of marigold. Bioresource Technol. 81:103-108.

[6] Ayyobi H, Olfati JA, Peyvast GA. 2014. The effects of cow manure vermicompost and municipal solid waste compost on peppermint (Mentha piperita L.) in Torbat-e-Jam and Rasht region of Iran. Int J Recycl Org Waste Agric. 3:147153.

[7] Bacigalupe LD, Araya NM, Carter MJ, Catalán TP, Lardies MA, Bozinovic F. 2007. Maternal effects, maternal body size and offspring energetics: a study in the common woodlouse Porcellio laevis. Comp Biochem Phys A. 147:349-354.

[8] Bian Z, Wang Y, Zhang X, Li T, Grundy S, Yang Q, Cheng R. 2020. A review of environment effects on nitrate accumulation in leafy vegetables grown in controlled environment. Foods. 9:732.

[9] Cakmak I. 2008. Enrichment of cereal grains with zinc: Agronomic or genetic biofortification? Plant Soil. 302:1-17.

[10] Castañeda LE, Lardies MA, Bozinovic F. 2004. Adaptive latitudinal shifts in the thermal physiology of a terrestrial isopod. Evol Ecol Res. 6:579-593.

[11] Catalán TP, Lardies MA, Bozinovic F. 2008. Food selection and nutritional ecology of woodlice in Central Chile. Physiol Entomol. 33:89-94.

[12] Cataldo DA, Haroon M, Schrader LE, Youngs VL. 1975. Rapid colorimetric determination of nitrate in plant tissue by nitration of salicylic acid. Commun Soil Sci Plant Anal. 6:71-80.

[13] Colla G, Kim HJ, Kyriacou MC, Rouphael Y. 2018. Nitrate in fruits and vegetables. Sci Hortic-Amsterdam. 237:221238.

[14] Da Silva Junior FMR, Silva PF, Guimaraes FS, De Almeida KA, Baisch PRM, Muccillo-Baisch AL. 2014. Ecotoxicological tools for landfarming soil evaluation in a petrochemical complex area. Pedosphere. 24:280-284.

[15] Dallinger R, Wieser W. 1977. The flow of copper through a terrestrial food chain. I. Copper and nutrition in isopods. Oecologia. 30:253-264.

[16] Drobne D. 1997. Terrestrial isopods-a good choice for toxicity testing of pollutants in the terrestrial environment. Environ Toxicol Chem. 16:1159-1164.

[17] Edwards CA, Burrows I. 1988. The potential of earthworm composts as plant growth media. In: Edwards CA, Neuhauser E, editors. Earthworms in Waste and Environmental Management. the Netherlands: SPB Academic Press; p. 21-32.

[18] EU Commission. 2020. The European Green Deal https://eur-lex.europa.eu/legalcontent/EN/TXT/?qid=1596443911913\&uri=CELEX:52019 DC0640\#document2
[19] Ghemari C, Bouslama MF, Ayari A, Nasri-Ammar K. 2016. Population structure and dynamics of Porcellio laevis (Latreille, 1804) in Northern Tunisia. Vie et Milieu. 66:209218.

[20] Guiterrez-Miceli FA, Santiago-Borraz J, Molina JAM, Nafata CC, Abud-Archila M, Llven MAO, Rincon-Rosales R, Dendooven L. 2007. Vermicompost as a soil supplement to improve growth, yield and fruit quality of tomato (Lycopersicum esculentum). Bioresource Technol. 98:27812786.

[21] Farooq M, Almamari SAD, Rehman A, Al-Busaidi WM, Wahid A, Al-Ghamdi SS. 2021. Morphological, physiological and biochemical aspects of zinc seed priminginduced drought tolerance in faba bean. Sci HorticAmsterdam. 281:1-7.

[22] Folguera G, Bastias DA, Bozinovic F. 2009. Impact of experimental thermal amplitude on ectoterm performance: Adaptation to climate change variability. Comp Biochem Phys A. 1543:89-393.

[23] Ghoname AA, Riad GS, El-Bassiony AMM, Tantawy AS. 2017. Biofumigation with fresh manure or Brassicaceae residuals could be a promising methyl bromide in head lettuce production. Gesunde Pflanz. 69:29-37.

[24] Gorenjak AH, Cencic A. 2013. Nitrate in vegetable and their impact on human health. A review. Acta Aliment Hung. 42:158-172.

[25] Hale HM. 1927-1929. The crustaceans of South Australia. Parts I and II. Reprinted 1976. Adelaide: Flora and Fauna Handbooks Committee; AB James, Government Printer.

[26] Harding PT. 2016. Is Porcellio laevis (Latreille) declining in Britain and Ireland? Bull Brit Myr Grp. 29:23-27.

[27] Hernandez A, Castillo H, Ojeda D, Arras A, Lopez J, Sanchez E. 2010. Effect of vermicompost and compost lettuce production. Chil J Agr Res. 70:583-589.

[28] Hussein MA, Obuid-Allah AH, Mohammad AH, ScottForsmand JJ, Abd El-Wakeil KF. 2006. Seasonal variation in heavy metal accumulation in subtropical population of terrestrial isopod, Porcellio laevis. Ecotox Environ Safe. 63:168-174.

[29] Kammenga JE, Dallinger R, Donker MH, Kohler HR, Simonsen V, Triebskorn R, Week S. 2000. Biomarkers in terrestrial invertebrates for ecotoxicological soil risk assessment. Rev Environ Contam T. 164:93-147.

[30] Kiran S. 2019. Alleviation of adverse effects of salt stress on lettuce (Lactuca sativa var. crispa) by application of vermicompost. Acta Sci Pol-Hortoru. 181:53-160.

[31] Krug H. 1991. Gemüse Produktion (2. Auflage). Berlin und Hamburg: Verlag Paul Parey.

[32] Lardies MA, Cotoras IS, Bozinovic F. 2004. The energetics of reproduction and parental care in the terrestrial isopod Porcellio laevis. J Insect Physiol. 50:1127-1135.

[33] Lardies MA, Bozinovic F. 2008. Genetic variation for plasticity in physiological and life-history traits among populations of an invasive species, the terrestrial isopod Porcellio laevis. Evol Ecol Res. 10:747-762.

[34] Leamsomrong K, Suttajit M, Chantiratikul P. 2009. Flow injection analysis system for the determination of total 
phenolic compounds by using Folin-Ciocalteu assay. Asian J Appl Sci. 2:184-190.

[35] Liebster G. 1990. Warenkunde, Gemüse (2. Auflage). Düsseldorf: Morion Verlagproduktion GmbH.

[36] Lim SL, Wu TY, Lim PN, Shak KPY. 2015. The use of vermicompost in organic farming: overview, effects on soil and economics. J Sci Food Agr. 95:1143-1156.

[37] Loureiro S, Sampaio A, Brandão A, Nogueira AJA, Soares AMVM. 2006. Feeding behaviors of the terrestrial isopod Porcellionides pruinosus Brandt, 1833 (Crustacea, Isopoda) in response to changes in food quality and contamination. Sci Total Environ. 369:119-128.

[38] Marshall RE, Farahbakhsh K. 2013. Systems approaches to integrated solid waste management in developing countries. Waste Manage. 33:988-1003.

[39] Mensinga TT, Speijers GJ, Meulenbelt J. 2003. Health implications of exposure to environmental nitrogenous compounds. Toxicol Rev. 22:41-51.

[40] Montgomery DC. 1991. Design and analysis of experiments. New York: John Wiley and Sons Inc.

[41] Nair GA 1976. Life cycle of Porcellio laevis (Latreille) (Isopoda, porcellionidae). Proceedings of the Indian Academy of Sciences - Section B. 84:165-172.

[42] Nagavallemma KP, Wani SP, Lacroix S, Padmaja VV, Vineela C, Rao MB, Sahrawat JL. 2006. Vermicomposting: recycling wastes into valuable organic fertilizer. J Agric Res. 2:20-37.

[43] Odendaal JP, Reinecke AJ. 1999. Short-Term toxicological effects of cadmium on the woodlouse Porcellio laevis (Crustacea, Isopoda). Ecotox Environ Safe. 43:30-34.

[44] Orozco FH, Cegarra J, Trujillo LM, Roig A. 1996. Vermicomposting of coffee pulp using the earthworm Eisenia fetida: Effects on $\mathrm{C}$ and $\mathrm{N}$ contents and the availability of nutrients. Biol Fert Soils. 22:162-166.

[45] Pearson D. 1970. Analysis, Determination of L-ascorbic acid. International Federation of Fruit-Juice Producers, No: 17.

[46] Pierce WD. 1907. Notes on the economic importance of sowbugs. US Department of Agriculture the Bureau of Entomology Bulletin, No 64, 15-22.

[47] Rehman A, Faroq M, Asif M, Ozturk L. 2019. Supraoptimal growth temperature exacerbates adverse effects of low Zn supply in wheat. J Plant Nutr Soil Sc. 182:656-666.

[48] Salehzadeh H, Maleki A, Rezaee R, Shahmoradi B, Ponnet K. 2020. The nitrate content of fresh and cooked vegetables and their health-related risks. PLoS ONE. 15:e0227551.

[49] Sharma RC, Banik P. 2014. Vermicompost and fertilizer application: Effect on productivity and profitability of Baby Corn (Zea mays L.) and soil health. Compost Sci Util. 22:83-92.

[50] Tuzel Y, Oztekin G, Tuzel IH, Duyar H. 2020. Growing media in organic seedling production. Ege Universitesi Ziraat Fakultesi Dergisi. 57:603-610. Turkish

[51] Warburg MR. 1993. Evolutionary Biology of Land Isopods. Berlin: Springer-Verlag.

[52] Yamaguchi M. 1983. World vegetables: New York (NY): Van Nostrand Reinhold Company.
[53] Zimmer M. 2002. Nutrition in terrestrial isopods (Isopoda: Oniscidea): an evolutionary-ecological approach. Biol Rev. 77:455-493. 